\title{
Effects of Different Levels of Four Herbicides Used as Preemergent Treatment on the Lstablishment of Centipede Lawn Grass (Erimochloa ophiuroides)
}

\author{
S. J. Rodriguez and Angel R. L'eliberty ${ }^{1}$
}

INTRODUCTION

Centipedegrass (Erimochloa ophiuroides) seems to be a well-adapted lawn grass for Puerto Rican conditions. It is gencrally propagated through divisions of the bunches and stolons, but the ground surface requires constant weeding by hand or hoe until the stolons cover up the ground and can compete with weeds. Since housing construction is a major industry in Puerto Rico, and lawn establishment is the main part of the landscaping, and very costly, it was of interest to see how certain herbicides used as preemergent treatments would control the developing weeds and, at the same time, how they would affect the growth of the grass. This article summarizes the results of a trial carried on at the Gurabo Substation in which four commercial herbicides aflocted weed population, as well as the development of the lawn.

\section{MATERIALS AND METIODS}

The following herbicides were used as preemergent treatment in the trial: Simazine [2-chloro-4,6-bis(ethylamino)-s-triazine], atrazine (2-chloro-4 ethylamino-6-isopropylamino-s-1riazine), diuron [3-(3,4 dichloroplenyl)1-1-dimethylurea], monuron [3-(p-chlorophenyl)-1-1-dimethylurea]. ${ }^{2}$ Commercial formulations in the form of wettable powder containing 80 percent of the active ingredients were used in the test. The rates of application of the first two herbicides were $2,4,8,16$ and 32 pounds per acre, while the last two were applied at 1, 2, 4, 8 and 16 pounds per acre, on the assumption that they would be effective at lover rates than the previous two.

A tract of Mabi clay land was prepared by plowing and racking for the propagation of centipedegrass. The usual method for the preparation of the soil consists in plowing at a depth of 6 to 10 inches. After about 2 weeks the soil was racked to leave the area as smooth as possible. The Mabí

${ }^{1}$ Associate Horticulturist and former Researeh Assistant in Agronomy, Gurnbo Substation, University of Puerto Rico, Río Piedras, P.R.

2 The first two herbicides were products of the Geigy Agricultural Chemicals Ardsley, N.Y. The other two, supplied as Kiumex and Telvar, were products of the E. I. Dupont de Nemours and Co. (Inc.), Wilmington, Del. Trade names are used in this publication solely to provide specific information. Mention of a trade name does not constitute a guarantee, warranty, or endorsement by the Agricultural Experiment station as superior to these or other similar products not mentioned. 
soil is a heavily impervious soil from a colluval origin present in formes of the last condeal jart of the Island.

Tho propagation was done by planting divisions from bunches and stolons in holes at abont 8 inches apurt. In the area, 25 square foot plots wox separte for the herbicides treatments. A 2 foot border was left anong trested phots.

The herbides mentioned above were applied with a knilysack syuryer by suspending the required quintity of cach for each plot in enough water to cover the area. The suspended herbicide was applied as uniformly as possible to the whole plot. The treatments were randonly distributed in each replication whore four replications for the experiment were provided.

The emerging woeds were harvested after a month from herbicide application. No selaration as to weed species was carcied out. $A$ count on the dead-grass bunches was caried on at the same lime. The effect on growth whis nuasured by hivesting the developing stolons after 2 months from treatments. Circon woight in both cases was obtained by weighing in a Meller antomatic balance in the laboralory.

The data were analyzed through analysis of variauce and regression analysis.

\section{RESUTTS AYD DISCUSSION}

The elfects of the four herbicides on weed control and growth of centipedegrass are presented in table 1 , and figures 1 and 2. Though the analysis of varianes showed differences among individual treatments, the overail effect of the rates of the different herbicides used were not clearly estahlished from the resultis. A regression curve was fitted to the results to determine the overall effect on weed control and growth (figs. 1 and 2). Since no provision was made to separate the weeds as to species, regression malysis showed that none of the four herbicides at the different rates prevented the development of weeds in the plots. The main reason for this was that the predominani weed was uutgruss (Cyperus rotundus), which a)pears to be resistant to the herbicides used even at the high rates used.

In most cases, the leaves of this weed showed some yellowing, but later on the weed reemerged from the underground stem. Since the experiment was carried on in a heavy clay soil there apparently was very little downward movement of the herbieides. There is evidenee of this in that the downward movement was slower in heavier thon in lighter textured soils $(2,6,7,8,10,11)$. $^{3}$

'There is also the possibility that the herbicides wed were absorbed through the leaves, no translocation oceuring in the underground part that is generally a food reserve for the development of nutgrass.

\footnotetext{
${ }^{3}$ Ttalic numbers in parentheses refer to Jiterature Cited, p. 24 ,
} 
We are dealing with herbicides the mode of action of which is by inhibiting photosynthesis $(1,3)$. There is evidence of lack of downward translocution of certain herbieides $(5,9)$; moreover, Crentner and Hilton (4) found that, when barley leaves were furnished with outside sucrose through the lonf-lips, they were able to withshand lethal doses of phonylurea herbicides. In our case the underground stem served as a ready sourec of food for further germination and growth.

Tares 1. Fifferts of promergent trealment of 4 herbicides monesd eontrol and growth of centipede lawn wiass

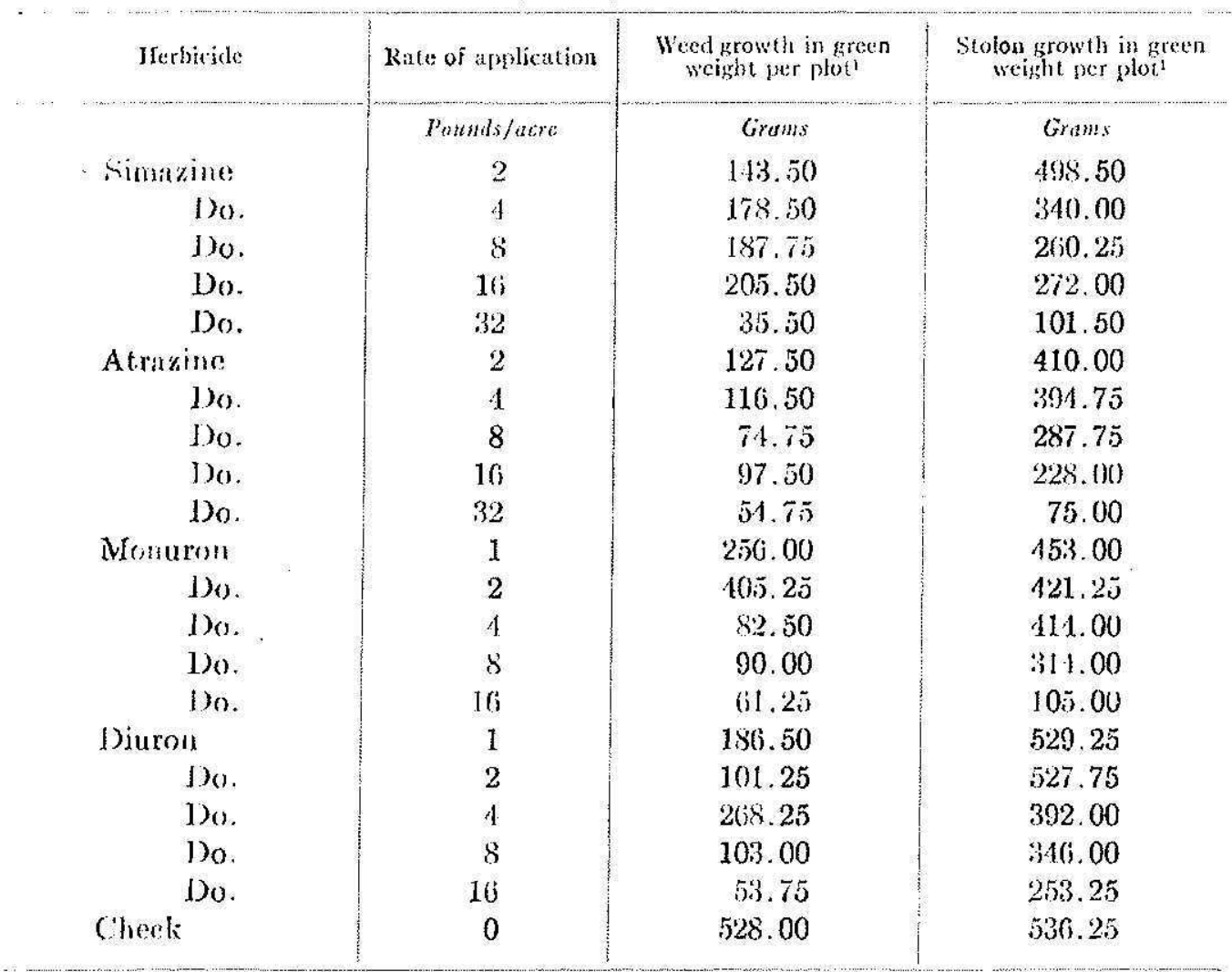

1 Mean values are averages for 4 replications.

The effects of the diflerent concentrations of the four herbicides on the growth of rentipedegrass are presented in table 1, but can be more clenty seen in figure 2 . As expected, the higher the coneentration the greater was the restriction in growth. Many of the original stolous were killed by the herbicides, especially at concentrations above 8 pounds per acre. In all (ases the restriction on growth was signiticant or highly significant. Apparently in the urea-substituled herbicide the restriction is less at the lower mes, while in the two triakne herbicides the drop is steadier.

For pracical purposes none of these herbicides should be used at rates 


\section{4}

JOURNA, OF AGRICUITURE OF UNCYERST'T OW PUERTO RICO
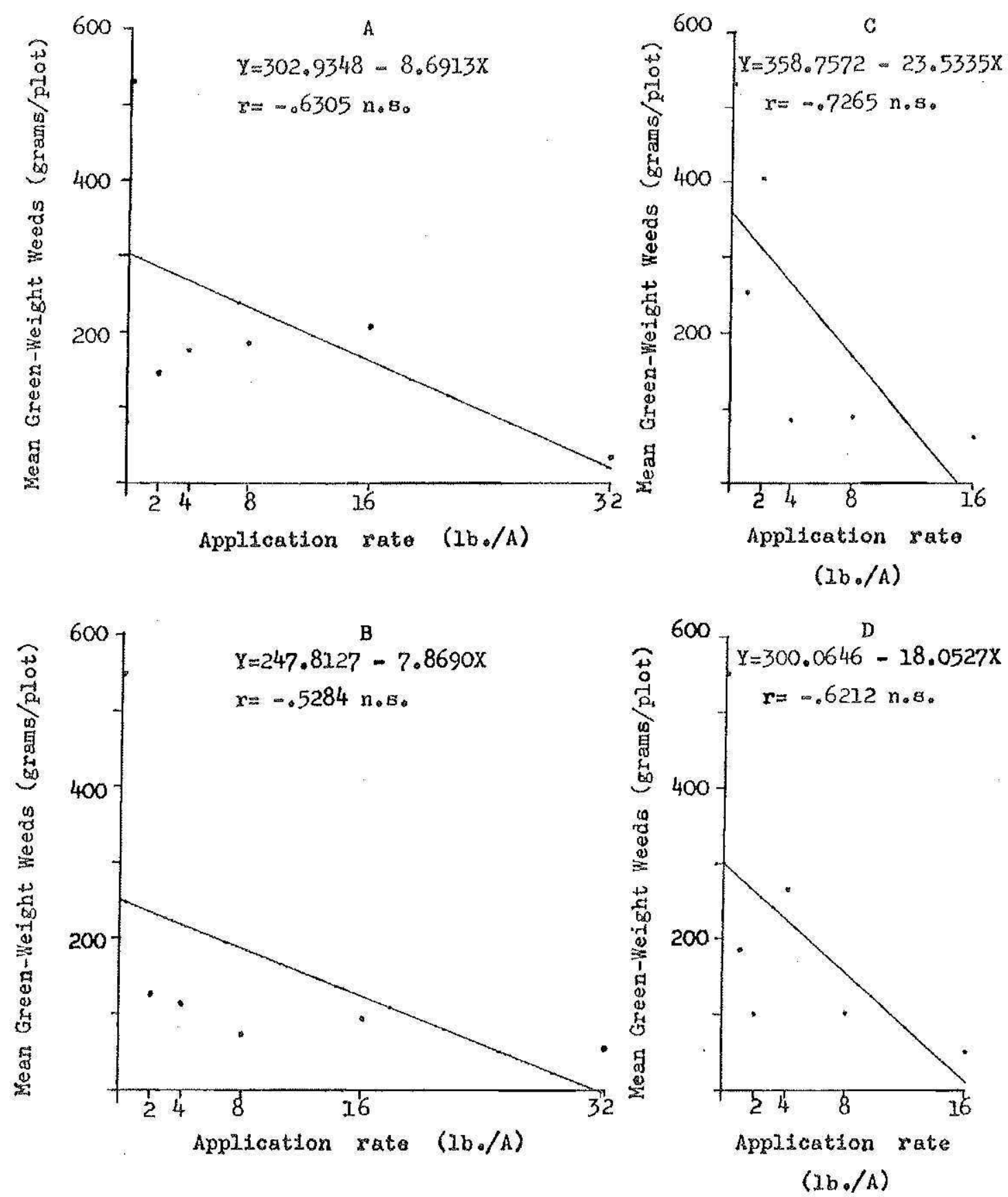

Fra. 1.- Regression curves of the eftect of different levels of herbicides on weed growth in centipedegrass: A, Simazine; B, atrazine; C, monuron; D, diuron.

above 4 pounds per acre because of the restriction in growth, since the homeowners are interested in having a cover as soon as possible. The rate of application should be lower for the two phenylurea herbicides than for the two triazine herbicides. 

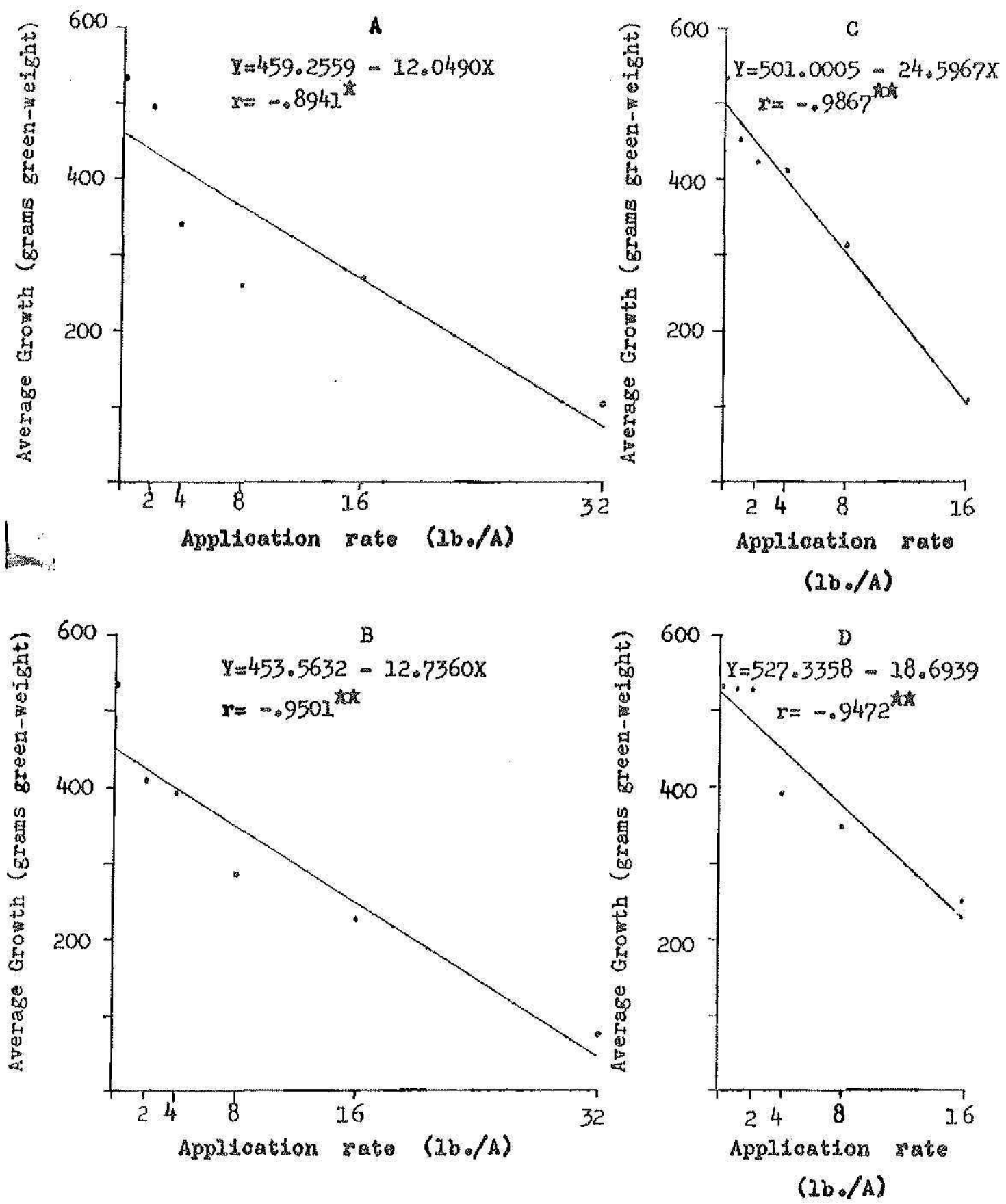

Fia. 2.- Regression curves of the effect of diferent levels of herbicides on growth of entipedegrass: $A$, Simazine; $B$, atrazine; $C$, monuron; D, dinron.

\section{SUMMARY}

Four herbicides: Monuron [3-(p-chlorophenyl)-1-1-dimethylurea], diuron [3-(3,4 dichlorophenyl)-1-1-dimethylurea], atrane (2-chloro-4-ethylanino-6-isopropylamino-s-(riazine), and simazine $[2$ chloro-4, 6 -bis (ethyl- 
amino)-s-triazind wore lested at fivo levols as preemorgent treatments in the establishment of rentipede lawn grass. None of the four provided good control of weeds, since the predominating weed was nulgruss which seems resistant to the herbicides used. All lonr restrieted the stolon development and sprad of the grass studied, esperially when the mates were over 2 pounds and 4 pounds per acre for the phenylureas and triazines herbicides, respectively.

\section{RRSUMYN}

Se probó la acción preemergente de cuatro yerbicidas: Monuron [3-(p)dorofeníl)-1-1-dinetiluoa], diuton [3-(3,4 dielonofeníl)-1-1-dimetilureal),

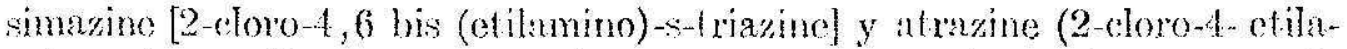
mino-6 isopropilamino-s-trinzine), al establecerse an césped de gruma de la variedad Giompiés. Ninguno do los yerbicidas dio resultado satisfartorio, debido al predominio del Cocui, yerbajo que aparentemente posce una alta resistencia a los yerbicidas que se usaron. Los eutro yerbicidas afectaron desfavorablemente el crecimiento de la yetba Ciempiés, registrándose los peores resultados a este resperto cundo se usaron sobre 2 libras y 4 libras de las ureas y las triminas sustifutivas, respectivamente.

\section{DITERATURE CITED}

1. Ashtom, Floyd M., Zweig, Gunter, and Mason, C. W., The eflocts of certain triazines on $\mathrm{C}^{14} \mathrm{O}_{2}$ fixation in red kidney beans, $W_{\text {eed }} 8$ : 448-51, 1960.

2. Burnside, O. C., Fenster, C. R., and Wicks, G. A., Dissipation and leaching of monuron, simazine, and atrazine in Nebraska soils, Weeds 11:209-213, 1963.

3. Cooke, Anson R., A possible mechanisn of action of the urea type herbicides, Weeds 4: $397-8,1956$.

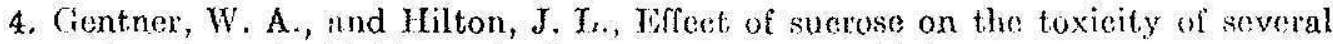
phenyluren herbicides to barley, Weads 8: 413-7, 1060.

5. Haun, J. R., and Peterson, J. H., 'Translocation of 3-(p-chlorophenyl)-1-1-dimethylurea in plants, Weeds, 3: 177-87, 1954.

6. Ogle, R. R., and Warren, G. F., Fate and activity of herbicides in soils, Weeds g: $257-73,1055$.

7. Rahn, L. M., and Baynard, R. E., $\mathrm{J}$ r., Persistence and penetration of monuron in asparagus soils, Weeds $6: 432-40,1958$.

8. Sheets, 'T. I., 'The comparative toxicities of four phenylurea herbicides in several soil types, Woeds 6: 413-24, 1958.

9. - Uptake and distribution of simazine by oats and cotton scedlings, Weels 9: $1-13,1961$.

10. Sheets, T. J., and Craits, A. S., The phytotoxicity of four phenylurea herbiendes in soils, Weeds 5: 93-101, 1957.

11. Sherburne, H. R., Fred, V. H., and Fang, S. C., The use of $\mathrm{C}^{14}$ earbonyl labeled 3-(p-chlorophenyl)-1-1-dimethylurea in. a leaching study, Weeds 4: 50-4, 1956. 